\title{
DE GEBOORTE VAN DEN HOOGEN RAAD VAN HOLLAND EN ZEELAND
}

\author{
DOOR \\ Mr. A. S. DE BLECOURT, \\ Hoogleeraar te Leiden.
}

In den zomer van 1919 stelde Mr. W. Tonckens J. L.zN. mij een bundel aanteekeningen ter hand, door hem deels uit gedrukte, deels uit ongedrukte bronnen getrokken, alle betreffende de wording en de ontwikkeling van den Hoogen Raad van Holland en Zeeland. Het was zijn voornemen geweest zelf deze aanteekeningen te verwerken tot een opstel, dat reeds was aangekondigd in zijn Grammatica Latina van Vossius, opgenomen in de Bijdr. voor Vad. Gesch. en Oudh., 5e reeks, 6e deel, 191.9, bl. 64 e. v.; hij meende echter om gezondheidsredenen beter te doen het werk niet voort te zetten, en verzocht $\mathrm{mij}$ die taak van hem over te nemen. Tk aanvaardde die taak, doch bedong eenig nitstel, dat langer duarde dan mij lief was. Het besiuit van Mr. Tonckens eerbiedigende, betreur ik het toch, dat hij niet zelf de uitwerking van zijn plan heeft roltooid; gelukkig echter bleek reeds een groot stuk geheel of zoo goed als geheel voor den druk in gereedheid te zijn gebracht, zoodat ik slechts weinig er aan had toe te voegen. Ik meende niet beter te kunnen doen dan Tonckens' werk, voorzoover het persklaar was, ongewijzigd over te nemen.

Wat nu volgt, is van 'Tonckens; het in den tekst met kleine letters opgenomene en de noten zijn van mij, tenzij anders is vermeld.

Zoowel tijdens de republiek, als onder de grafelijke regeering, bestond in Holland, het vroegere graafschap, de latere provincie, 
een "Hof van Holland" 1). De naam was dezelfde, de zaak versohilde. Het oude Hof was een grafelijke regeeringsraad, tevens belast met rechtspraak. De instructies voor het Hof (die van 1462, van Kared den Stoute, toen nog Karel vas Charolais, die van 1531, van KAREL $V$ ) regelden zoo goed als uitsluitend de rechterlijke functies; de regeeringsbevoegdheden waren meer zaak van practijk ${ }^{2}$ ). In beide functies had W ILlEM vaN Oranja, als Stadhouder van den Koning-Graaf, het Hof leeren kennen. Die kennis had hem geleerd, dat die beide functies niet behoorden te zijn in ééne hand, wellicht ook dat, afgescheiden daarvan, de samenstelling van het Hof te wensehen overliet ${ }^{3}$ ). Van die verkregen kennis maakte hij gebruik, toen de omstandigheden in 1572 hem stelden aan het hoofd van den opstand.

In den voorzomer was het Hof van Holland uit den Haag gevlucht, met al zijne ap- en dependenties. De uittocht schijnt een soort van optocht geweest te zijn. Alles trok mede naar Utrecht; slechts één der raadsheeren (Mr. ADRIAAN YaN DER Hourf) bleef achter, ging althans niet mede, en niet alleen de beambten en bedienden, maar zelfs de advocaten, op een drietal na, onder wie de jonge Oljenbaranvelt, togen mede. Men nam de reis over Haarlem, kampeerde daar in den Hout, en hield te Utrecht zitingen in Paushuize. Over den tocht kan men bij Yan Menteken en Bor Iezen ${ }^{4}$ ). Van de komedie-vertooningen in Paushuize, die slechts konden dienen, "ut aliquid fecisse

1) Over de ontwikkeling van het Eof van Holland zie men Focresa ANores, Bijdragen tot de Nedl. Rechtsgcseh., IV, bl. 407 e. v., en de daar vermelde literatunr. Voeg daarbij: Mr. G. W. Vreege, De Hooge Raad oan Holland, Zeeland en Wesi-Vriestand, in Jaarb. woor de Regterl. Magt in Ned., $1839-1844$.

2) Men vindt die instructies gedrukt in het Groot Placoaatboek, III, bl. 631 c. v., en II, bl. 703 e. v.

3) Trouwens, de splitsing, zij het nimmer geheel volgehouden, tusschen politie en justitie, gold in lie dagen reeds sinds lang in land, stad en dorp.

1) V:N Mleterin, fol. 83, ed. 1623; Bor, to druk, fol. 289 ; 29 druk, bl. 397. Deze vermeldt, dat het Hof in Utrecht niet veeI te doen had, omdat het grootste deel van Holland reeds tot den Prins was overgegaan. Bon vermeldt verder (op fol 289,10 druk; bl. 397,20 druk), dat 't Hof zich te Utrecht vestigde nomtrent Sint Maartensdam"; Mr. S. Musule Fz.; Oude Huizen te Utrech, bl. 28, vermoedt dat dit in Paushuize geweest zal zịn. 
videatur", is (zeker opzettelijk, omdat het al te fraai zou wordea), naar het schijnt, geen audientieblad of procesverbaal gehouden, althans niet bewaurd.

De Prins deed, alsof hij de vlucht van het Hof betreurde. Hij sommeerde de heeren, om terug te keeren. Of deze nsommatie" hen bereikte, is de vraag; zeker is, dat ze er niet aan voldeden, wat trouwens door den Prins even weinig verwacht als gewenscht zal zijn. Ze moest natuurlijk dienen, om een zekeren grond te geven aan, voor te bereiden wat volgde. Dat vervolg was de benoeming (op voordracht van de "Staten van Holland") door den Prins, bij besluit van 3 Novernber 1572, "gedaen tot Haellem", van een "president", een "raedt ende procureur generael" en zeven "raiden" (alle meesters in de rechten) in het nieuue Hof 1 ).

De bedoeling van deze benoeming was, ,dat goede justitie geadministreert mach werden". Bepaald werd dat de benoemden, nvolgende 's Hoofs Instructie" (d. i. die van 1531), zullen „recht wijsen bij arreste" (d.i. zonder hooger beroep). Denzelfden dag nam de Prins nog een ander besluit, eveneens te Haarlem en ook op voordracht van de "Staten van Holland", war.bij tien heeren, waaronder twee meesters in de rechten, werden benoemd, die „meest continuelijk neffens zijne Excellentie souden wesen, omme met deselve te besoigneren, raetslagen ende te helpen resolveren 't gemeen beste van denzelven lande."

Legt men de 2 resoluties naast elkaar, dan ligt de conclusie voot de hand, dat deze tien heeren, voor 't meerendeel niet-juristen, met de politieke zaken zouden worden belast, en het andere consortium, de president en raden van den hove, lonter met de justitie.

De inhoud dezer twee resolutiën volgt hier:

„Den Prince van Orangien, Grave van Nassau, ete., Stadhouder van Hollandt, Zeelandt, Vrieslandt ende Vuytrecht, eto.s, begerende den Ruedt Provinciael van Hollandt te redintegreren ende de plaetse to vervullen van dengheenen, die boirtuluchtich zijn, ten eynde dat goele justitie wederom ge-

1) Den 25 Aug. 1572 verzocht de Prins den Staten van Holland een vonsdracht te doen voor den nieuw te benoemen provisioneelen Raad van Holland (Groot Placcuatboek, III, bl. 32-34). 
administreert mach werden, heeft bij advise ende denominatio van den Staten van Hollandt de vacerende personen" [lees: plaatsen] "gegeven de personen, hiernaer genomineert: Meester Jax yas Tresiong, President, meester Willem in: Cock, raedt ende procureur-generael; raiden: meester Nikolas van dea Lase; meester Anrlaex van dex Hourf; meester Cornelis van der Bouck-

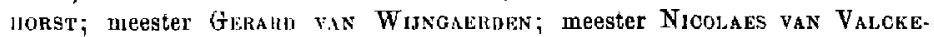
jteyn; meester Dienick vas des Nieudohch; meester Petel van der Mefh. Ordonneert rijne Excellentie, dat de commissie voir den bovengen. president ende raiden gedepescheort werde in behoirlijoker ende gewoonlijcke forme", [zoo] "zij luyden die begheeren te accepteren 1), ende dat dezelve, den eedt gedaen hebbende, wnyt orahte van dien ende volgens 's Hoofs instructie '), recht wijsen bij arreste, doende heurluyder sententiën executeren, zonder eenighe appellatiën atn te sien, zoo lange ende ter tijt toe dat hel acces lot den Grootes Thedl tot Meshelen wederomme geopent zij. Gedaan tot Haerlem, op den 3den Novembris, anno XVC twe en 't zeventioh."

Hier volgt het ander besluit van 3 November 1572 , hondende de benoeming van de politieke heeren 3 ).

Den Prince van Orangiëu, Grave van Nassau, enz., Stadhouder en de Capiteyn Generael over Hollandt, Zeelandt, Westvrieslandt, etc., oversien hebbende

1) Hieruit vloeit dus voort, dat dit stuk, dat Kuur geet' in zijn Historie der Holl. Stcatsreg., III, bl. 420, gedrukt is naur een afschrift van de minuut dezer commissie, uit het door hem als zonderling betiteld register. Aan de benoemden zou dus deze anstelling, deze commissie, "gedepescheert" worden; dit geschiedde, echter niet in den vorm van een afschrift maar in nitvoeriger vorm; nen vindt afgedrukt bij KLuIT, a.w., III, bl. 422/425, een afschrift dier commissie, zooals ze den benoemden raadsheer Connels van Bouckhorst is toegezonden. In dit stuk wordt wel is waar, evenals in de hierboven afgedrukte commissie, den benoemde tot taak gesteld recht en justitie te administreeren (dus rechtspraak alleen), maar dan volgt, dat dit geschiedt tot "conservatie van Zijne Majesteits hoocheyt ende heerlicheyt", en van de "gemeyne welvaert", die "sonder justitie ende ordre politycque" niet zou blijven "subsisteren". Dit is te lezen, alsof de leden van 't Hof bleven belast met "zaken van politie"; 't is ook als 't constateeren van een gevolg van 't achterwege blijyen van administratie der justitie op te vatten. (Zie de volgende noot).

2) Deze verwijzing naar de instructie van 1531 alsmede het "redintegreren" van den raad provinciaal, in den aanhef vermeld, geeft voedsel aan de opvatting, dat 't oude Hof is horsteld met de oude, deels politieke, taak. Intnsschen de Prins kon altijd later, met de 2 besluiten van 3 November 1572 in de hand, verklaren dat dit anders was en dat de instructie van 1581 van het opgeheven Hof, hoezer dit zaken van justitie en politie beide behartigde, richtsnoer bleef voor 't nieuwe Hof, dat enkel de justitie had te dienen.

3) Het is ontleend an hetzelfde ${ }^{\text {zonderlinge" }}$ register, en gedrukt bij KLulT, a. w., III, bl. 319. 
de persoonen, zijne Exeell. bij geschrifte overgelevert, onme daer vuyt te verkiesen zeecker getal, die vuyt den name ende als volcomelijck geauthoriseert van den Staten van Hollandt ende Westurieslandt meest continuelijck neffens gịne Excellentie souden wesen, omme met dezelye te besoigneren, raetslagen, ende te helpen resolveren 't gemeenbeste van denselven lande, heeft daer vuyt verkosen dieghenen, hiernaer genomineert". Volgen de namen. "Gedaen tot Haerlem, den Baen Novembris anno XVC twe en 't zeventich.

Het stuk, houdende annstelling der raden van het Hof, is ook gedrukt in het bekende artikel van BAKHUIZEN VAN DEN BirNk, de eerste vergadering der Staten oon Holland, opgenomen in Het Nederl. Rijksarchief, 1857; zie bl. 15) aldaar ').

Opmerking verdient dat bij de instelling van het nieuwe Hof de Prins bepaalde dat het zal "recht wijgen bij arreste" en daaraan toevocgde: ${ }_{n}$ doende heurluyder sententien executeren, zonder neenighe appellatien aen te sien, zoo lange en ter tijt toe dat het acces "tot den Grooten Raedt tot Mechelen wederomme geopent zij". Voorloopig was dus dit Hof in Holland de hoogste rechter.

De Prins was in die dagen $d e$ man, en de raden in het Hof zullen wel dankbaar geweest zijn voor hunne benoeming. Maar

1) Mr. Tonckess teekent omtrent deze stukken aan: Een gelukkig toeval heeft gewild dat deze belangrijke stukken (zij het niet in originali) bewaard zịjn gebleven. Ze zijn (blijkbaar door een verzamelaar) gecopieerd in het "zonderling register", waaraan KLuIT ze in 1803 ontleende, dat (zooals hü zegt) "tot heden onbekend" was, hem (blijkbaar bij toeval, en na het verschịnen van zijn eerste deel) in handen $\mathrm{kwam}$, en thans berustende is op het Algemeen Rijksarchief, - genummerd Holland 1788 - waarvoor het, blijkens een op het stuk gestelde annteekening, is angekocht op "cene anctic bij Scheurleer te 's-Hage, 16 December 1844, no. $95 \mathrm{~m}$. s." Hoezeer Kucur met dat "zonderling register" niet recht weg wist, heeft hij aan de veridiciteit (terecht m. i.) evenmin getwijfeld als Balchuizen vas des Brisk, die het door hem afgedrukte besluit ook daaruit overnam. Deze staat vast, als men de geschiedenis nagaat van den eersten tijd van het nieuwe Hof van Holland, waarvoor จ. a. te raadplegen SLrCHER, "Register van de namen en wapens van de Raden "en Ministers van het Hof van Holland, 1425-1787", een merkwaardig stuk, waaraan veel moeite is besteed, en waarin, na eene "Korte beschrïving" betreffende het onde Hof van Holland, is opgenomen eene "Korte aanteekening" over de "vernieuwing" van 1572, die echter met voorzich tigheid moet worden geraadpleegd. De besluiten warden genomen door "Den Prince aan Orangiën, Grave van Nassau, etc., Stadhouder ban Hollandt, Zeelandt, Yrieslandi ende Uytrecht etc., dus op zïpn naam. Dit verdient de andacht om de in 1573 door het Hof tegen dien vorm gevoerde oppositie, waarover nader. 
al spoedig stond het creatuur op tegen zijn schepper. Het nieuwe Hof hield zijn eerste zitting te Delft 13 Februari $1573^{1}$ ) en reeds 30 Juli daaraanvolgende begon het zoeken van spijkers op laag water. Op zeer eigenaardige wijze, die aantoont dat de heeren of hunne (nieuwe) positie niet begrepen, ò trachtten te reageeren.

De zaak was deze: de Prins stelde verordeningen vast op zijn naam, wat zeer natuurlijk was en van zelf sprak. Maar dit viel niet in den smaak van het (nieuwe) Hof van Holland. Omdat het oude lichaam van dien naam (als regeeringsraad) had deel genomen aan de wetgeving, traehtte het nieuwe Hof gelijke positie in te nemen. De verordeningen moesten (natuurlijk), om te binden en toegepast te kunnen worden, afgekondigd zijn. Die afkondiging had sedert lang plaats door voorlezing in eene zitting van het Hof, of liever na afloop van de sitting, ten overstaan van de suppoosten en van het publiek. De "raden" luisterden deze plechtigheid niet op door hunne tegenwoordigheid. Van zoodanige af kondiging bleek door een verklaring van den griffier van het Hof. Oorspronkelijk werd die verklaring gesteld op een afzonderlijk papier (perkament), dat aan het afgekondigde stnk werd vastgehecht, geattacheerd. (Vandaar dat die afkondiging in de praetijk den naam attache verkreeg.) $\mathrm{Zij}$ werd echter later vervangen door eene aanteekening, op het afgekondigde stuk zelf ( wat zeer practisch was, maar de afkondiging bleef den naam attache behouden.

Een voorschrift omtrent deze afkondiging bestond vóór 1531 niet. Maar ,omme te schuwen inconveniënten, die wel eer ghebeurt "zijn" (natuurlijk hierin bestande dat de afkondiging verzuimd was of daarvan niet naar behooren bleek), schreef Keizer KAREL in de Instructie voor het Hof van dat jaar, in $\$ 221$, voor, dat ${ }$ van nu voortaen de mandementen ende brieven, bij Ons of onsen ${ }_{n}$ Raedt geexpedieert, niet ter executie gelegt en sullen worden "binnen onsen Lande van Hollant, Zeelant ende Vriesland, sonder „alvooren van onsen Rade van Hollant te hebben behoorlicke „attache". Zooals boven vermeld, had de Prins, bij besluit van 3 November 1572 het nieuwe Hof instellende, bepaald, dat het

1) Zie Kluit, a. w., 1, bl. 73; zie ook Bol, I, 6e boek, le druk, fol. 302; $2 e$ druk, bl. 414. 
recht zoude spreken naar deze Instructie. En nu bericp het Hof zich op deze paragraaf 221 , om aanspraak te maken op medezeggenschap bij het maken van verordeningen, en om te betoogen dat deze niet door den Prins op zijn naam, maar op dien van den Koning-Graaf, moesten worden uitgevaardigd. En vandaar het verzoek van 30 Juli 1573 , dat de Prins geen placcaten zou afkondigen zonder attache van het Hof. Het Hof zag voorbij, dat het besluit van 3 November 1572 - de grond van zijn bestaan ook door den Prins op eigen naan was genomen. (Zie bl. 432, noot 1). Een schijntje van grond kan men gezocht hebben in de omstandigheid, dat de Staten in 1572 den Prins hadden erkend als 's Konings Stadhouder, wat hij sedert 1559 werkelijk was geweest, maar in 1567 had opgehouden te rijn. De neiging voor mystificatiën. was in die dagen zeer sterk ${ }^{1}$ ).

Het Hof was, als gezegd, volgens het besluit van 3 November 1572 , in Holland ${ }^{2}$ ) voorloopig de hoogste rechter. Echter slechts voorloopig, want aan het slot van het besluit had de Prins de heropeuing van "het acces tot den Grooten Raedt tot Mechelen" als mogelijkheid in het vooruitzicht gesteld. Die groote Raad van Mechelen was een college van hooger beroep, door de Bourgondische en Oostenrijksche vorsten voor "de Nederlanden", - voor "onse. landen van herwaerts over", "nos pays de par-deca" - ingesteld, met de bedoeling om van hunne Nederlandsche gewesten eene eenheid te maken. Dat de ingenomenheid met de instelling, in den beginne althans, niet groot is geweest, moge blijken uit het feit, dat aan Maria van Bodrgondiü bij het Groot Privilege onder meer de bepaling werd afgedwongen door de Staten-Gene-

1) De gedrukte en ongredrukte bronnen van het hier meegedeelde zijn te vinden bij KıuIT, a. w., I, bl. 73 e.v. Ze zijn door Mr. Tonckens oppieuw geraadpleegd. KLLiT zegt, op bl. 74, dat 't Hof dit verzoek niet deed als justitie-, maar als politieke raad.

2) Bij de Unie susschen Holland en Zeeland van 15 April 1576 , stelde ook Zeeland zich onder het nieuwe Hof, gelijk het onder het onde had gestaan. In 1576 werd 11.l. bepaald: "Zijne Exc, sal vanwegen den Coningh, als Grave van Hollant ende Zeelant, reoht onde justitio doen administreren bij dé Raed Provinciael van den Hove van Hollant over alle plaetsen ende ingezetenen van Hollant, Zeelant ende Vrieslant" etc. In de twee volgende artikelen wordt de competentie van 't Hof geregeld. (G. P., II, bl, 2133, 2134). 
raal, „dat de consistoriën van den Parlemente ende andre te Hechelen, onlancx upghezet, cesseren zullen'. 1). De Groote Raad van Mechelen was daardoor niet meer de bevoegde rechter in hooger beroep. Maar die reehtsmacht trad weer in, toen het Groot Privilege, met de andere privileges, die sedert den dood van Karis nen Stovte verleend waren, door PhIlirs den Schoone, werd "gerevoceert en gecasseert" op 12 December 1494, toen hij bij zijne inhuldiging de andere privileges bevestigde $\left.(G . P ., I V, \text { bl. } 8)^{2}\right)$. Zoo was dus weer de Groote Raad van Mechelen opperste Gerechtshof voor de gewesten, die stonden onder de heerschappij der Oostenrijksche vorsten, en werd hij dat onder K.AREL $V$ voor al de Nederlandem. Voor Holland hield dit - feitelijk - op met het slagen van den opstand, en die toestand werd formeel bevestigd door het meermalen vermeld besluit van den Prins van 3 November 1572.

Herstel van dat hooger beroep op den Grooten Raad van Mechelen werd in 1572 natuurlijk door niemand in Holland gewenscht of verwacht. Waarom makte de Prins er melding van aan het slot van zijn besluit van 3 November, warbij hij het nieuwe Hof instelde? licht wordt hierop geworpen door hetgeen sedert $1 \overline{0} 72$ ten aanzien van hooger beroep van de beslissing van het Hof van Holland voorviel, en waaruit blijkt, dat de Prins grooten prijs stelde op dat hooger beroep, maar allerminst (natuurlijk) op dien "Grooten Raedt tot Mechelen", zoolang de stad Mechelen en omgeving in Spaansche handen was ${ }^{3}$ ).

De eerste jaren na 1572 waren te onrustig, om and dat hooger beroep veel aandacht te wijden en het te regelen. Maar de Prins verloor het door hem reeds 3 November 1572 zoo belangrijk geachte punt niet uit het oog. Nadat de zaak op 12 November 1574 en 8 Maart 1575 reeds in de vergadering der Staten was geweest, liet hij 16 April 1575 door den "Advocaat" PaUuUs Burs, den voorganger van OLdenbarnevelt, de Staten "voorhouden", dat dit hooger beroep moest worden geregeld. Reeds 5 dagen later,

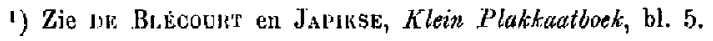

2) Volgens Meyer, Institutions judiciaires, IV, bl. 203, werd pas in 1503 de Groote Raad van Mechelen ten opzichte van Holland en Zeeland in zijn vorig gezag hersteld.

3) Zie P. L Multar, Gouden Eeuw, 10 druk, II, bl. 126. 
21 April $15 \overline{75}$ (uit den korten termijn is af te leiden, dat de Staten zonder veel bedenking hebben gedaan wat door den Prins werd voorgesteld), besloten de Staten dat de sententiën van den Hove van $f 800$ of lager, in weerwil van appel, ,executie zullen hebben onder cautie", en die van hooger bedrag of eenig "factum" medebrengende, slechts na eene ,ordonnantie" van den Prins, of van degenen, die tot eene summiere revisie van zulke sententiön door den Prins en de Staten zouden worden gecommitteerd, zoowel uit het college van den rade zelf als andere ${ }^{1}$ ). Niettemin zouden de partijen, die geappelleerd hadden, „blijven in haar geheel", om hun appel te vervolgen, „hetzij voor den Grooten Raad van Mechelen, of elders, daar "zulx bij advise van Zijn Excellentie en de Staten van Holland en Zeeland geordonneert zal worden". "Of elders"; de Groote Raad van Mechelen raakt langzamerhand van de baan. Het beshuit van 21 April 1575 gold zoowel voor de reeds ingestelde nappellatiën", als voor latere. Met dit besluit was de instelling van een college van hooger beroep slechts in vitzicht gesteld 2). Den 12 den December 1577 verscheen de ordonnantie, die, in afwachting van een regeling van het appel, een voorloopige regeling van revisie behelsde, en is opgenomen in het Groot Placcaatboek, II, bl. 1498. Dit stuk is niet zonder strubbeling in de wereld gekomen. Den 15 den November 1577 was het concept van die ordonnantie door de Staten gezonden arn het Hof van Holland bij den volgenden brief:

1) Uit deze resolutie volgt m. i. dat voor elke zaak, waarin revisie werd verzocht, reviseurs zouden worden aangewezen. Dus geen vast college van reviseurs. Men vindt in de resolutiën der Staten van Iilaliand op 29 Juli, 6 Sept. 24 Sept., 5 Nov. 1576, 8 Febr., 17 Mei en 24 Juni 1577, telkens benoemin. gen van revisenrs, overeenkonstig de res. van 21 April 1575.

2) Ook de Pacificatie van Gent van 1576 behield lierstel van 't gezag van den Grooten Raad van Mechelen voor. Op verzoek van partijen zelf vonden de Staten echter 20 April 1575 goed de stukken van zeker proces over te brengen naar den Grooten. Raad van Mechelen, die wij kennen, zeggen de Staten, „voor den Grooten en Souvereinou Raedt van deze Sijn Majesteits Nederlanden, deer wij geen vijandechap tegen hebben". Over deze en dergelijke ficties, en over het daarmee verband houdend gebruik der Staten, om ordonnantiën en placeaten op naam van Prilips uit te vạardigen, behoeft hier niet te worden gesproken. 
Fdele, Wịise, Voorzienige, Hoochgeleerde Heeren,

Alzoo Wij tot vorderinge van der justitie ende omme te verhoeden alle vordere clachten, die op $t^{\prime}$ stuck van de appellaciën van alle sentenciën van den Hove van Bollandt bij partijen tot noch toe zijn gedaen, bij provisie zeeckere ordre daerinne hebben gesteld, achtervolgende d'ordonnancie, hierneffens gaende, ten eynde partijen nyet rechtelves en blijven, maer justitie geadministreert mach worden naer behooren, soe hebben $W_{\text {ij }}$ Uwer $\mathrm{E}$. bij desen wel willen verzoucken, d'zelve ordonnancie ter audiëncie te willen doen publiceren 1), ten eynde nyemant daervan ignorancie preteadere. Ende zoeverre bij Uwer $\mathbf{E}$. eenige merckelicke swaerigheyden daerinne bevonden zouden mogen worden, sullen dezelffde Uwer E. nyet nalaten, ons metten eersten op onse vergaderinge alhier daervan t'adverteren, ten eynde vorder daerinne gedaen mach worden naer behoren.

Hiermede, Edele, Wijse, Voorsienige, Hoochgeleerde Heeren, onse Heere Godt zij met Uwer E. Geschreven tot Leyden, den XVon Novembris, 1577.

T'er ordonnancie van de Staten van Hollandt, bị mị : De Rechtere.

De schrik sloeg den raden in het Hof om het hart. Revisie van hunne sententiën! 2) Reeds 21 November ging de volgende brief af, blijkens aanteekening op de minute, gearresteerd ${ }_{n}$ in den vollen raidt":

Aen Mïnheeren, die Staten van Hollandt, Zeelandt ende West-Vrieslandt.

Edele, Vermoegende, Eersaeme, Wyse, Voorsinnige Heeren,

Wij hebben ontvangen eekre Uwer U.E. missive van date den XVen Novem. bris deeser jegenwoerdigen maent, met sekere ordonnancie op 't stuck van de appellatiën gemaeckt. Ende alsoe Uwe U.E. ons versoucken, dat zij die voorochreven ordomancie souden publiceren ter audientie van de rolle, ten waero wij daerinne eenige merckelicke zwaericheyd bevonden, daervan wij Dwen $\mathrm{E}$. in sulcken gevalle souden adverteren, soe hebben wij die voorscreven ordonnancie te saemen gevisiteert, ende gecommitteert onse medebroeders in Rade Mrg. Dikk van oeh Nenburch ende Heronimus van Borre, omme dienthalven met Uwer E. te spreeken, Uwer M. E. biddende, die voorscreven onse medebroeders geboor ende geloef te willen geven aengaende 't gundt zij dieselve Uwer E. soe noepende die voorscreven ordonnancie als andere saecken, die justitie betreffende, van onzentweegen aendienen sullen. Ende hiermede otc. Edele etc. ut supra. Gescreven in den Haege den XXIen Novembris 1577.

1) Dit is de ,attache".

1) De sinds 1575 voorloopig in zwang gebrachte revisie (bl. 435-6) stond hun blïkbaar niet aan. 
De gecommitteerden werden, blijkbaar met bekwamen spoed, door de Staten ontvangen en gehoord, maar hadden geen succes, zooals blijkt nit de missive, die door het Hof 28 November aan den Prins werd gericht (blijkens aanteekening op de minute, gearresteerd in eene vergadering van het Hof, waarin anwezig waren de raden Houff, Nienburch, Borre, Casentrood, Brasser, Brederode, v. Loen en Menfre) van dezen inhoud:

An de $\mathrm{Ex}_{\mathrm{x}}$ van de Prince van Oraigne.

Doorluchtige, Hoechgeborne Furst, Genaedige Heer,

Wij hebben van de Staten van Hollant ontfangen selcre missive van date den XVen deeser jegenwoerdiger maent, met sekre ordonnantie, bij hen op 't stuck van de appellatiën gemaeckt, versouckende die voorsc. Staten bij de voorse, missive aen ons, dat zij die vonrse. ordonnantie ter audientie van de rolle alhier souden doen publiceren, ten waere nochtans ons eenige redenen moveerden ter contrurie, daervan zij dieselve Staten in sulcken gevalle souden veradverteren. Ende daerinne bevindende eenige zwaricheden, habben deselve bij forme van remonstrantie bij geschrifte doen stellen, ende voorts gecommitteert onsen medebroeders in Raede Mrs. Denfinck van oea Nifurinch ende JeroNislis VaN BolltE, omme diesaengraende mondeiinge metto voorsereven Staten van onsentweegen te communiceren, die oic omme die oorsaeke in den (Hage?) bij de voorsoreven Staten geweest zij $n$. Ende alsoe die voorsereven commissarissen ons gerapporteert hebben, dat die voorscreven Staten van meyninge zijn, nietjegenstaende die voorsereven onze remonstrancie, die voorecreven ordonnancie ons eerstdaechs over te senden, onme albier publiceert te werden, soe hehben zij Uwer Princelijjcke Excellentie deervan wel willen verwittigen, ende voorts dieselve oversenden die voorsereven ordonancie ende remonstrantie, omme dienthalven van. Uwer Princelijgke Excellentie, als wesende 't hoeft van den Lande ende justitie, te weeten Uwer Princelijcke Excellenties goede meininge ende jutentic, ofte dieselve ordonnantie publiceren sal dan niet, ende, diervan geexhorteert; sullen ons daernae gaerne reguleren. Doorluchtige etc., XXVIIJ Novembris 1577 .

De in dit schrijven bedoelde remonstrantie schijnt verloren gelaakt te zijn en van de mondeling aangevoerde bezwaren geen aanteekening gehouden. Men weet dus niet, wat het Hof tegen den roorgenomen maatregel inbracht. Dat het geen succes had ook bij den Prins, blijkt uit de afkondiging van de ordonnantie, die 12 December 1557 werd vastgesteld. Haar inhoud is, in verschillende opzichten, merkwaardig genoeg, om deze (gedeeltelijk) bier te doen volgen. 
(Hier houdt het opstel van Tonckens op; in hetgeen volgt, heb ik echter dankbaar gebruik gemaakt ran de door hem verzamelde en te mijner beschikking gestelde aanteekeningen.)

"Philips", enz.

${ }_{n}$ Also tot vorderinge van den justitie hoognoodigh bevonden is goede ordre te stellen ende te voorzien op 't stuck van de appellatiën van alle sententiën diffinitive, bịj die van onsen Rade Provinciael van Hollandt", enz., ngewesen ende die noch sullen mogen gewesen werden, ter tijdt toe 't resort van onsen Grooten Raede wederonme plaetse sal mogen hebben, 't welck door den inlantschen krijgsberoerte, eenige jaren ende als noeh in dese onse Nederlanden wesende, seer qualijeken heeft konnen ende mach geschieden", en\%. "Soo ist, dat wy, by advise ende deliberatie van onsen lieven ende welbeminden neve, Ridder van onser Ordre van den Gulden Vliese, den Prince van Orangien, voor Ons Stadthouder ende Capiteyn Generael orer Hollandt", enz., "ende oock ghehadt 't advijs van onsen Raede van Hollandt, mitsgaders van de Ridderschap, Edelen ende gedeputeerden van de steden van Hollant ende Zeelandt", enz., "ordonneren by desen, dat alle sententiën, nae de publicatie van desen bij den voorsz. Raede te wysen, voorts aen sullen gehouden worden voor arreste, in der voegen dat degeenen, die by de voorsz. ghewesen sententiën hen sullen bevinden heswaert, in de platse van de gewoonlycke appellatie van de voorsz. sententiën sullen mogen versoecken revisie binnen 20 dagen nae de pronunciatie van dien" 1). Ook van de vóór de publicatie van dit placcaat gewezen sententiën van 't Hof van Holland voorzoover daarvan was geappelleerd, doch om de bekende reden zonder dat er gevolg aan was gegeven, zou revisie openstaan binnen 20 dagen na de publicatie van dit placcaat, en in al deze gevallen moest 't verzoek tot revisie gedaan worden aan den Stadhouder en bij diens afwezen aan de Staten of derzelver gedeputeerden; hangende 't verzoek van revisie werd de uitvoering' van de sententie geschorst, voorzoover deze veroordeeling bevatte tot betaling van meer dan $400 \mathrm{Car}$.gl. of een condemnatio ad factum.

1) Dus: van de sententiën van het Hof van Holland stond geen beroep open, gelijk weleer op den Grooten Raad van Mechelen, doch in de plaats daarvan voorloopig revisie. 
„Ende.ten eynde een yegelijcken, 't sy ingesetenen van den lande van Hollandt ende Zeelandt ${ }^{1}$ ), ofte d'uytheemsche, door de voorsz. versochte revisie recht ende justitie sal moghen ghenieten, sullen onsen voorsz. Stadthouder, die Staten voornoemt, ofte Hare Gedeputeerde gehouden wesen te committeren 9 persoonen, als 3 uyttet collegie van den voorsz. Racde, die over die sententiën ghestaen sullen hebben, ende 6 andere, alles, ofte 't mecrendeel van dien, rechtsgeleerde wesende", welke zes personen beëedigd zullen worden. M. a. w. zon men zeggen: voor elke revisie moesten telkens reviseurs worden benoemd; immers er staat, dat er over moesten zitten 3 radsheeren uit het Hof, die over de te reviseeren zaak gezeten hadden. Dan zou er dus niet zijn een vast college van reviseurs, evenmin als later na do oprichting van den Hoogen Raad van Holland en Zeeland, toen ook voor elke revisie reviseurs werden angewezen. Het slot van 't placaat geeft echter den indruk, dat er vaste reviseurs werden ingesteld; immers er staat dat de reviseurs bun besognes zullen aanvangen den len Maart 1578.

Zooveel is zeker, dat voor de periode, die nu volgt de thans kort te bespreken resolutiën geen uitsluitsel geven, of er nu was één past stel reviseurs, of dat er telkens opnieuw jeviseurs voor elke zaak werden benoemd. Tk geloof dat de toestand was als volgt: De Staten benoemden zes reviseurs, gekozen buiten de leden yan 't Hof om, en deze zes waren voor alle revisieaanvragen en zij kozen voor elke zaak 3 raadsheeren uit 't Hof om ze mede in revisie te behandelen. Mijn hoofdargument is, dat niet meer als voorheen benoeming van reviseurs roor een zaak in de resoluties voorkomen. De andere argumenten kan de lezer zelf uit hetgeen rolgt, afleiden.

Het schijnt dat de regeling van 12 December 1577 niet heeft voldaan. Ten minste op 12 September 1578 besloten de Staten van Holland, dat v. b. MijLe, v. D. MEEr en Hogevees, als gecommitteerden ad hoc, die oude resolutie van 21 April 1575 zouden „redresseeren". Van dit redres verneemt men echter verder niet; den 16en. Januari 1579 immers besloten de Staten de ordonnantie op 't stuk van de revisie te arresteren, en te doen ydepescheren op de naem ran den Koningh" en die te doen publiceeren; men

1) Over dit "ende Zeelandt" straks nader. 
vindt deze ordonnantic op de revisiën in 't Groot Placcanthoek, II, bl. 1502 ; het is een uitwerking, niet van de resolutie van 21 April 1575, maar van de ordonnantie van 12 December 1577. Ik teeken er uit aan, dat de commissarissen ter revisie hun ,audientie ende raedkamer" zouden houden "binnen den Hage op 't Hof, tot sulcken plaetse als henluyden ,door den Staten ghedesigneert sullen werden."

We hebben gezien dat volgens de regeling van 12 December 1577 de Stadhouder of wel de Staten zouden aanwijzen de 9 reviseurs en wel 3 raadsheeren uit het Hof, die de te revideeren sententie mee gewezen hadden, en 6 buiten het Hof. Op dit punt wordt den $16 \mathrm{en}$ Februari 1579 een wijziging aangebracht; dan besluiten de Staten dat de zes reviseurs, die de Staten annijzen (buiten de leden. van 't Hof om, is bedoeld) de $\mathbf{3}$ reviseurs uit de leden van het Hof zullen aanwijzen, mits onder dit drietal steeds gekozen worde de raadsheer-rapportenr en de beide anderen, op wie de keuze valt, over de bestreden sententie gezeten hebben. De zes zijn m. i. de vaste, de drie de losse adviseurs. Tenzelfden dage wordt de advocaat ADRIaen van DER MrJus geexcuseerd van de besogne op 't stuk van de revisie (dit slaat $m$. $i$. terug op de resolutie van 12 September 1578, hierboven vermeld, waarbij v. D. MiJLE tot die besogne was verkozen). Den 11 en Mei 1579 besluiten de Staten de verdere besognes over de regeling der revisie te schorsen totdat Zeeland zal hebben geantwoord; en na nog 2 resoluties over dit onderwerp, van minder belang, n.l. van 18 en 29 Mei 1579, wordt op 30 Mei 1579 tot de hervatte besogne den Zeeuw Mr. Cornelis De Backbre toegelaten, ofschoon Zeeland nog niet had toegestemd in de ordonnantie op de revisie. De gecommitteerden van de revisie leggen 1 Juli 1579 den eed af in banden van gecommitteerden uit de Staten van Holland.

Dat er inderdaad een vast college voor revisie was sinds de resolutie van 1577 , blijkt $m$. i. nog uit het besluit dat de Staten van Holland op 11 Juni 1580 namen. Dirk Cornelisz. MoL, van Rotterdam, was den 12 en October 1579 bij sententie van het Hof rau Holland gehandhaafd in bezit van tienden. Er was in deze zaak door de Commissarissen van revisie provisie verleend en dit doen de Staten nu te niet, evenals de procedure die er op is gevolgd, omdat in materie van possessie geen 
revisic valt. Indien er voor elke revisieannvrage revisemrs moesten worden aqngewezen, dan zou deze beslissing onzin zijn. Zeeland is in deze geschiedenis van revisie en appel van de sententiën van het Hof niet asustonds Holland gevolgd. Zeeland had n.l. 23 Januari $1578^{1}$ ) rijn afgevaardigden in den Haag instructie gegeven, mede te deelen dat Zeeland er niet in toestemde, dat de sententiën van den Hove onder cautie executabel, en arresten zouden zijn, zooals Holland had besloten en mede op naam van Zealand afgekondigd. (Dit slaat op het placcaat van 1577, zie bl, 440.) Den 5en Juni 1578 besloot Zeeland wèl toe te stemmen in een nienwen revisieraad, met effect van appellatic, mits $1 / 3$ der radsheeren Zeeuwen waren. M. a. w. wèl een college van hooger beroep boven 't Hof', en dan voor $1 / 3$ met Zeeuwen bezet, geen revisie op de wijze, door Holland in de praktijk gebracht. Den 7en Januari 1579 adviseerden Middelburg, Zierikzee en Goes in de vergadering der Staten van Zeeland, „op de saecke ende instructie van de revisie in Hollandt", dat zij wenschten te houden het privilege van te appelleeren op Mechelen; Vlissingen verklnarde geen last te hebben orn hierover stem uit te brengen, Veere wilde de zaak in commissie gegeven zien; 't resultaat was, dat men 10 Januari 1579 de gedeputeerden naar Holland opdroeg mee te deelen, dat "deselve revisie in Zeelandt alsnoch nyet practicabel en werdt bevonden, midts de diversiteyt van de opiniën desen aengaende onder de Staten". Den 12en Augustus 1579 heeft Zeeland een soortgelijke aanmerking gemaakt op het vonnis wijzen vau 't Hof bij arrest, als zoo even vermeld, thans naar aunleiding van een concept van de ordonnantie op de kleine zaken. Deze ordonnantie, den 21en Dec. 1579 (G. P., II, 762 e.v.) door de Staten van Holland vastgesteld, stelden de Staten van Zeeland den $29 \mathrm{en}$ d.a.v. in handen van gecommitteerden ter fine ran rapport; eenige dagen te voren, 21 Dec. 1579, hadden de Staten van Zeeland hun gedeputeerden ad hoc opgedragen een instructie te ontwerpen voor een provincialen raad in Zeeland; dit beteekende dus afscheiding van 't Hof van Holland; den 1en Maart 1580 besloten zij Holland te be-

I) Ik raadpleegde voor deze Zeenwsche zaken de bij Martinus Nijhoff in 1916 en volgende jaren uitgegeven notulen van Zeeland. 
richten, dat zij de ${ }_{n}$ nieuwe instructie opte cleyne saecken" goedkeurden, behalve op 't punt dat de sententiën door' commissarissen zouden worden gewezen; dit moest, dachten zij, door 't Hof zelf geschieden, en deze sententiën van den Hove moesten dan bij provisie geëxecuteerd kunnen worden onder cautie, niettegenstaande appel, zulks, $0 m$ te schouwen meerdere nieuwicheyt ende pluraliteit van instantiën in Holland", wat bezwaarlijk is voor de Zeeuwen. Voorts geven zij er hun misnoegen over te kennen, dat ook deze ordonnantie is gepubliceerd "tot laste van onse ondersaten, aleer wijluyden daerin eyntelyck gecondescendeert hadden". Verder zeggen zij, dat het "hooch noodich is eens een eynde te maecken van de questiën" omtrent het vonnis wijzen bij arrest; aangezien op een vroeger voorstel geen antwoord is gekomen van Holland on dit dus als nict aangenaam beschouwd kan worden, stelt Zeeland mu voor, dat "bij provisic on totte openinge van 't resort van Mechelen", men zou appelleeren van 't Hof van Holland op den "Secreten Raedt", te Antwerpen, recht doende op de instructie van den vroegeren "Grooten Raedt" van Mechelen, mits deze Secrecte Raad werd aitgebreid met eenige randsheeren, die met Holland en Zeeland bekend waren.

Aan dit voorstel van Zeeland waren roorafgegaan een paar merkwaardige besluiten in de Staten van Holland. Nadat den 29en Juni 1579 de besugnes over de revisie waren uitgesteld tot na de vacantie, hebben de Staten op 30 Juni 1579 ,rapport genomen", of er "bij forme van appellatie" (inplaats van revisie) met een gestadigh collegie binnen Hollandt sal mogen werden ghebesoigneert, op de ordonnantie ende instructie, die in den Grooten Raedt tot Mechelen wort geobserveert, omme alle kosten van de processen te verhoeden". Deze resolutie is in geen anderen zin op te vatten dan dat de Staten van Holland zelf hier aan-. sturen op het vestigen van een vast college van hooger beroep boven 't Hof van Holland, een plaatsvervanger dus van den Grooten Raad te Mechelen.

Den 18en September 1579 besluiten de Staten van Holland, dat er een Groote Raad te Haarlem zal worden opgericht, "daervoor van de sententiën van den Rade Provinciaal soude mogen worden geprovoceert", en in aansluiting hiermee volgt deze merkwaardige resolutie van dezelfde Staten, van 21 November 
1579, dat "tot vordering van de saten van justitie, met constitutie wan den Grooten Racedt tot Haerlem", alle steden zullen worden aangeschreven, elk 4 personen te benoemen, opdat daaruit de bekwaamste, "best vermaerste, gequalificeerste" gekozen moge worden, en deze Raad daardoor rzoo vermaerd worden moge, dat die van Dtrecht ende Vrieslandt hen daeronder mede mogen begeven". Deze resolntie tot aanschrij ving was 10 November 1579 voorafgegaan door een resolutie tot oprichting van den Grooten Raad te Haarlem, wat 18 September 1579 ook reeds was besloten. Maar op 21 December 1579 rees in de vergadering over de vestiging te Taarlem bezwaar: Dordrecht wilde dat niet, Leiden verklaarde er niet in te hebben geconserteerd, Gouda en Rotterdam wilden eerst de sinds lang in behandeling zijnde ordonnantie op 't redres der justitie xien afgedaan; Schiedam vroeg bedenktijd; de andere steden eischten dat deze zaak voortgang zou hebben. Verheugden die van Haarlem zich op het blij vooruitzicht in hun stad het hoogste rechtscollege gevestigd te zien, 't zou blijken verheugen met een doode musch te zijn, want den 2en Februari 1580 deelt Dordrecht ter Statenvergadering mee den Grooten Raad gevestigd te willen zien, niet in Haarlem maar in Antwerpen; de meeste steder en de edelen stemden voor Haarlem; men besloot advies in te winnen bij Zijn Excellentie. Reeds daags er na rapporteeren Gecomm. Raden nopens hun onderhoud met Z.E. Zij hadden Z.E. meegedeeld, dat sommige steden van oordeel waren, dat 't Hof moest wijzen bij arrest, andere, dat men „den Raad van Revisie" moest continuecren, dat de edelen en de meeste steden voor de oprichting van een Grooten Raad te Haarlem waren in de plats ran den Grooten Raad van Mechelen, terwijl Dordrecht den Secreeten Raad te Antwerpen wilde uitbreiden. Z.E. adviseerde continuatie van den Raad van Revisie. De Staten van Zeeland besloten 10 November 1579 de zaak der vestiging van den $H$. R. te Haarlem nog eens in bedenking te houden. In de Staten van Holland vielen nog tal ran besluiten in 1580 met betrekking tot de oprichting van deu Raad van Appèl of den Grooten Raad, zoo op 1 April werd andermaal Haarlem als zetel aangewezen, on besloten dat het zon zijn een raad vam appel in plaats van revisie en dat eenige personen zouden afdoen de processen, voor de commissie van revisie hangende; 5 Mei 1580 werd cen com- 
missie ingesteld om een instructie voor den Raad te ontwerpen, o.a. Oldennarnevelt nam zitting in deze commissie; denzelfden dag besioten de Staten, dat eerst de instructie voor den Grooten Raad zou worden gemnakt, alvorens de leden werden benoemd; roorts benoemde men zes personen, om bij provisie de zaken van revisie, die in staat van wijzen waren, te termineeren nevens 3 raadsheeren nit 't Hof, die bij deze zelfde resolutie hiervoor werden aangewezen; 7 Mei 1580 werden alle processen, waarin revisie was verzocht, gesurcheerd; 10 Mei 1580 klaagde het Hof bij de Staten vam Holland, dat hun college te zeer verzwakt was, nu er 6 uit hum midden waren geordonneerd op 't stuk van de revisie, waarop de Staten besluiten, dat de zaken van revisie zullen blijven behandeld volgens de laatste resolutie op dat stuk en voorts rapport te nemen op deze zaak; 10 November 1580 werden de raadsheer van der Mijle en Mr. Francols van Nrs aangewezen om mee recht te doen in den Haag in revisie; $11 \mathrm{Juni}$ 1580 werden de advacaat Burs en anderen angewezen, om de instructie te concipieeren voor den Raad van Appèl, die in Holland geconstitueerd zal worden.

Den 20en Januari 1581 wordt Mr. Gijsbrecht vay Hogrendorp, advoeaat, benoemd tot commissaris van de revisie, onder belofte dat, als er een raad van appèl komt, hij daarin als raadsheer zal ivorden gecontinueerd. Den 15 en Maart besluiten de Staten dat er een Rand van Appèl in Holland zal zijn, en 5 dagen later (20 Maart 1581) maken de Staten een nominatie op van 18, waaruit de Prins er 9 zal kiezen; de benoemden zullen eerst als commissarissen van revisie dienst doen, totdat de Raad van Appel is opgevicht. Nadat de Prins vervolgens zijn keuze had bepaald, besloten de Staten van Holland 4 Juli 1581, dat de Raad vooreerst in den Hoag you zijn gevestigd en dat de raadsheeren voor 't leven zouden worde:i benoemd.

Het salaris voor den President werd (5 December 1581) bepaald op 1200 pond en dat van de raadsheeren op 700 pond, behalve de „eeren, profijten en vrijdommen". Het salaris van den president 'Treslong, tot dusver president van 't Hof, werd 20 December 1581 dienovereenkomstig op $1200 \mathrm{pd}$. bepaald en de onderlinge rangorde der raadsheeren bij resolutie van 8 Januari 1582 vastgesteld. Ya ingekomen advies van den Prins, behandeld in de vergade- 
ring van 24 Juli 1581, was den 27 Juli 1581 besloten een commissie te benoemen, die eenige benoemden, die zwarigheden hadden hun benoeming te anvaarden, zou trachten over te halen dit nog te doen; de gecommitteerden ad hoc kregen macht hm een paar honderd pond meer te bieden boven 't vastgesteld bedrag. Den 22 September, 29 November en 5, 20 en 23 December 1581 vielen hieromtrent resoluties; die van 5 December is zoo even reeds vermeld. Den 18 en Januari 1582 werd Richard Barrador als gecommittecrde van de Staten van Holland opgedragen de Staten van Zeeland te wijzen op de goede commoditeit vóór die van Zeelend, om hich onder den pas opgerichten Raud van Appèl in Holland te stellen.

Den 3en Februari 1582 verzochten Gecommitteerde Raden die van den Rade Provincial ('t Hof m. a. w.), om op de rolle af te kondigen, dat de Raad van Appèl op Dinsdag 13 Februari 1582 zijn eersten rechtdag zou houden ter plaatse, waar de gecommitteerden tot de revisie roormaals hadden gebesogneerd. In het Groot Placcatathoek, II, bl. 1422, vindt men het deshetreffend Advertissement van den Hove. Op 24 Februarj 1582 benoemden de Staten een commissie, die in opdracht kreeg te onderzoeken, of het Predikheerenklooster in den Haag kan worden ingericht voor huisvesting van den Raad; doch den 10en April 1582 benoemden ze een andere commissic, om voor den $H$. R. in orde te brengen de kamer, waar de Staten zijn vergaderd geweest, en 24. April 1582 besluit men voor den $H$. $R$. een raadkamer in te richten hetzij op de keizerskamer, hetzij op de pijnkamer, en 25 April 1582 wordt gelast de pijnkamer op 't Hof te approprieeren tot audientieen pleitkamer van den $H$. $R$. en de kamer, waar de $H$. R. nu besogneert, n.l. de "Stove", in te richten tot raadkaner van dit college. (Wie over de huisvesting van den H. R. meer wil weten, raadplege of Rremlik, Beschr. van den Haug, T, bl. 130, e.v.)

Den 14 en Februari 1582 lreeg een commissie - waarin OtberBARNEVELT zitting had - opdracht de concept-instructie voor den $H$. R, met eenige leden van dit college te resumeeren en te arresteeren en den 13en April 1582 wordt bepaald, dat de instructie van den $H$. $R$. ter andientie zal worden gepubliceerd, wat men 24 April 1582 nog eens besluit, onder toevoeging, dat de $\mathrm{H} . \mathrm{R}$. ter audientie deze instructie zal publiceeren op naam van de 
Staten, in afwachting dat Zijn Excellentie ze zal hebben geconfirmeerd. In 't Groot Placcaatboek, II, bl. 790 e. v., en V, bl. 866 e. v. vindt men de instructie met de confirmatie van Prins WiLLEM, gedateerd 31 Mei 1582. Ze is gemaakt naar het model van de instructie roor den grooten Raad van Mechelen, opgenomen in G.P., $\mathrm{V}$, bl. 328 e. v. Het feit, dat de instructie eerst gereed kwam nadat het college al was geïnstalleerd, verklaart dat de H. R. (bljjkens den aanhef) gehoord is over zijn eigen instructie. (Zie het zoo even gemeld besluit van 14 Febr. 1582.)

Aan eenige raadsheeren uit den H. R., die klaarblijkelijk er op gesteld waren, in den Hang te blijven wonen, wordt beloofd (24 April 1582), dat, als dit college "quame te cesseren ofte te vertrecken" ('t was immers voorloopig in den Haag gevestigd, zie bl. 445 ), en rij niet begeerden te volgen, dat hun dan cen plaats in den "Raedt provinciael". (het Hof dus) zou worden gegeven. (Men vindt de voorafgaande data en feiten voor 't meerendeel ook bij P.estel, Commentarii de Republica Batava, III, bl. 744 e. v.)

Den H. R. werd 4 Sept. 1582 opgedragen af te doen wat ongedecideerd bleef hangen te. Mechelen, nadat te voren ( 1 en 27 Juni 1582) twee heeren (N1, VELil en de griffier GkNTS) waren gecommitteerd, om nachtervolgende de resolutio van de Staten Generaal" 1) te lichten de gefurnterde saken (sc. sacken) en processen, die voor den "Secreten Groten Raedt van Mechelen gediend hebben, concernerende de ingesetenen van Holland", en zich daartoe naar Mechelen te begeven. Soortgelijke resolutie namen 3 Februari 1582 de Gecommitteerde Raden, toen zij Dirk Jaysz. vAN WOERDEN gelastten, om nalle de registeren, sacken ende munimenten, under hem als griffier van de revisiën gelevert, gemaeckt ende alsnoch berustende, te leveren in handen van die van den Hoogen Rade, onder de bewaernisse van haerluyden griffier Anthonis Genirs 2). Tot mijn leedwezen heeft men ten Algemeenen

1) Dit slaat op straks te melden resolutie der S. G. van 25 April 1582.

2) Hoe klopt dit met 't verhual bịj Bor, dat toen Ou.ıvieir van ner Tempe. in Mei 1580 Mechelen voor de Staten won, de Staten „al de saken (sc. sicken) van de processen, den inwoonderen van Holland aengaende", van bem verkregen? Zijn ze toen geseponeerd blijven liggen in Mechelen? Zie Bon, 10 dr., fol. 192; 2e dr., bl. 175. De Staten schonken hem deswege, zegt Bor t. a. p., $2400 \mathrm{gl}$. 
Rijksarchieve deze stukken in 't archief van den H. R. van Holland en Zeeland niet gevonden. Het middel van revisie tegen sententiën van 't Hof' was thans dus vervallen. Het werd opnieuw' ingesteld tegen sententiën van den H. R. (Zie de Instructie voor den H. R, van 1582 , art. 279 e. v., G. P., V, bl. 892.)

In de Staten Generaal was in den jare 1582 de quaestie van de vervanging van den Grooten Raad van Mechelen ook ter sprake gekomen. De gedeputeerden van Holland hadden den 31 en Maart 1582 opdracht gekregen, om de zaak van den Hoogen Raad ter Gencraliteit te bevorderen, ten einde de instructie voor dit college mocht worden vastgesteld. Ik zou deze resolutie in dezen zin willen opvatten, dat het doel was de andere provincies te bewegen zich te stellen onder het college, welks tot standkoming. Holland toen reeds sinds 1579 bezig was voor te bereiden, on ten aanzien wanrvan men immers in de morkwaardige resolutie van 21 Nov, 1579 de hoop uitsprak, dat Utrecht en Friesland zich er onder zouden mogen begeven. De Staten-Generaal overwogen op 25 April $1582^{1}$ ), dat er weinig provinciën ressorteerden onder ..den Grooten Raedt, die eertijds tot Mechelen heeft geresideert", en er ook weinig meer onder zouden komen, indien „de voorn. Raedt wederomme opgerecht waere, overmits naer de gelegentheyt van een yder 7 den provincie daerinue anderssins is voorsien", zoodat zij besloten op voormelden dag, dat de Groote Raad „nu voortaenne sal cesseren ende affwesen”, en dat de processen, „aldaer bangende ongedeicideert" aan de resp. provinciën "gerenvoyeert" zouden worden, om aldaar beslist te worden door de Raden (= Hoven) of zulke personen als de "Hooge Overicheyt" daartoe zal aanstellen; voorts besloten de Staten-Generaal, dat er een "Raedt van justicie" nevens "Zijne Hoocheyt" (sc. Anjou) zon worden opgerieht, van 7 personen, die de provinciën zullen "nomineeren" op het "welbehaghen van Zijne Hoocheyt", welke raad kennis zou nemen van de "materieën, staende tot kennisse ende dispositie van den Prince van den lande" en vooral van de processen, die „noch moghen hanghen ongedecideert, zoo in den Grooten als Secreten Raedt als tusschen provinciën en de

1) JАPIKs, $456 / 457$. 
steden van verscheyden lantschappen." Hierop volgt den $29 \mathrm{en}$ April 1582 een resolutie van de Staten-Generaal 1 ), dat de provinciën binnen 14 dagen 22 personen zullen benoemen, waaruit $Z$. H. er 7 zal kiezen, "om in den voorsz. Raedt te dienen". "Hierop" - zegt BoR 2) - "hebben die van Holland verklaert, dat men de denominatie in de privé Raed van Sijn Hoogheid" (sc. den Raad van justitie nevens Z. H., waarvoor de provinciën immers gezamenlijk 22 zouden denomineren), ,soude laten desert lopen, also de tijd al was overstreken en 't land van Holland daardoor zoude mogen werden geprejudicieerd", waarnn zij njonkheer Willem vay Suilen van Nisvelí en Anthoni Genits, greffier", de processtukken lieten lichten tc Meehelen en zelf den Hoogen Raad in Holland oprichtten. Deze was er toen al; zie bl. 446. (Vgl. bl. 447.)

Alvorens nu uit deze drooge opsomming van resolutiën een conclusie te trekken ${ }^{3}$ ), nog een enkel woord over hetgeen Zeeland verder deed in deze quaestie van revisie en appèl van de sententiën, gewezen door 't Hof van Holland en Zeeland.

Nadat de zaak den 26 en Juni $15 \$ 1$ nog eens aanhangig was gemaakt bij de Staten van Zeeland, wordt 9 Maart 1582, zeker naar aanleiding van 't pleidooi van Holland's afgevaardigde Barrador (xie bl. 446), besloten an die van Holland te verzoeken alle stukken betreffende appèl eens over te zenden, opdat Zeeland er kennis van neme. Den 3en Juli 1582 hebben de Staten van Holland hun advocat Burs naar den Prins gezonden, opdat deze Zeeland zou mogen overreden zich onder den Hoogen Raad in Holland te stellen. Men vindt in de resolutiën van 1582 een ongedateerde en ongeteekende "Remonstrantie om mijnheeren de Staten van Zeelant to onderrichten, hoe nootelick dattet $x y$ de justitie alhier te doen administreren binnen de provincie by eenen Provincialen Raedt". Nu "het ressort ende authoriteyt van den Grooten Raedt tot Mechelen" heeft "gecesseert", moet hierin worden voorzien, zegt die Remonstrantie, want voor 't Hof van

1) Japikse, a. w., III, bl. $45 \overline{7} / 458$.

2) II, bl. 330 val den 2 en druk (fol. 29 van den len druk).

3) Men vindt bijna alle res. van Holland over ons onderwerp bijeen in: De oprichting van den Hoogen Raede in Holland wet hetgeen verder omtrent dat college bij de Heeren Staaten van Hollund en Zeelond beslowten is tot den juave 1767 (Utrecht. 1791). 
Holland hangen zoo'n massa Hollandsche en Zeeuwsche zaken, dat er geen afdoen aan is. Er moet op een nieuw middel gezonnen worden. De Zeeuwen moeten zich tot dusver behelpen met, , bij faute van cen provincialen raad," te "gebruycken ende oock te lyden d'authoriteyt van den Provincialen Raedt van Hollant, residerende in 's Gravenhage, sijnde een plaetse zeer diep in Follant gelegen ende die men uugt Zeelant nyet verzoucken en nach dan passerende veel mylen waters ende landts'. Tusschen Allerheiligen en Lichtmis wordt in Zeeuwsche zaken geen recht gedaan en vallen er geen defaulten; voeg daarbij de vacanties, dan ligt de conclusie voor de hand dat Zeeland meer dan de helft van 't jaar zonder justitie is. De "onnoosele" Zeelanders worden "getravailleert: ende uuytgestreken" door deurwaarders van 't Hof, zonder dat de Procureur-Generaal op deze excessen let. Zeeland lijdt onder de superioriteit van Holland; Holland heeft, ${ }_{n}$ om nog meerder superioriteit ende heerschappye te gebruycken", opgericht „eenen geheel nyeuwen Raedt, die syluyden noemen den Hoogen Raedt", en benoemen zoowel in den ouden provincialen raad als in dezen nieuwen hoogen raad, wie hun belieft, zonder cenige Zeelanders te "promoveren". Wijst Zeeland een raadsheer aan (in 't Hof'), dan moet deze nog. om "admissie" de Staten van Holland "solliciteren ende naeloopen". De Staten van Holland "onderwinden zich den voornoemden Provincialen Raedt absolutelick te commanderen, nyet alleen int maecken van de instructiën ende veranderinge van dyen, dan onck in wat raecken egeen recht gedaen ende wat sententiën nyet geëxecuteert zullen mogen worden", zoodat men dagelijks op de rolle van 't Hof hoort van zaken, die de Staten van Holland hebben geschorst of waaromtrent die Staten voorschriften hebben gegeven, waarnaar 't Hof zich moet "reguleren", zonder dat in deze zaken de Staten van Zeeland worden gekend. Overal kent men een eigen ${ }_{n}$ Raedt Provinciael", alleen in Zeeland niet. Men vindt in de Notulen der Staten van Zeeland van 1583, bl. 22 e. v., een conceptordonnantie voor een Provinciaal Hof van Zeeland, waarnevens gesteld: Exhibitum 1 Jajuari 1583.

De Staten van Holland probeeren 30 November 1583 nog eens Zeeland over te halen; men besluit den Prins te verzoeken Zeeland voor te stellen zich onder den $H$. R. te stellen en dat er dan 2 
raadsheeren uit Zeeland in dit college zitting zouden hebben, Nadat Mechelen in 1585 door PARMA was veroverd, was voor .7eeland alle kans om onder 't Hof te Mechelen te komen, voorbij, en stelde eerst Middelburg en daarna het overige Zeeland zich onder den Hoogen Raad in Holland, die van toen af dus werd een Hooge Raad van Holland en Zeeland. (Zie G. P., IV, bl. 552 e. v., 't verdrag met Middelburg van 10 Nov. 1586 ; G. P., IV, bl. 5004 e. v., 't verdrag tusschen de Staten van Holland en Zeeland van 29 Januari $\left.1587{ }^{1}\right)$.)

1) De gedeputeerden van Zeeland naar de Staten-Generaal kregen tegen de bijeenkomst van 1 Juni 1583 een lastbrief mee, waarin a. a. ten opzichte van 't hierboven aangeroerde punt van de voordracht van 22 personen, waaruit een Rad van Justitie nevens A njou zon worden benoemd, hun werd gelast. te verklaren, dat dit Zeeland niet raakte en dat men goed vond de provisionecle resolntie van de Generaliteit op dit punt. (M. a. w. men vond goed de res. der Staten-Goneraal van 25 April 1582; zie bl. 448; keurde af de res. van 29 April 1582 ; zie bl. 448/449.) Den 14en September 1583 delibereerden de Staten van Zeeland over het appèl tegen sententiën van 't Hof van Holland en Zeeland. Er was verzocht de Gedeputeerden ter Generaliteit volmacht te geven om tot een besluit te komen over "den voortganck van justitie in uiterste ressort", want bij gebreke van "uiterste ressort" kwam na "interjectje van appèl" de justitie stil te staan. Men besloot evenwel de zauk nog aan te zien. Toen in 1584 vacatures in den $H$. R. waren te vervullen en de Prins bij Zeeland er op aandrong zich onder den $H$. R. te stellen, opdat dan met een Zeenwsche raadshecren in deze vacatures konden worden benoemd, besloten de Staten in Maart 1584 nogmaals dit punt te laten rusten. Den 19en Maart 1585 wordt in de Staten van Zecland gewezen op 't feit, dat nu men geen "uiterste ressort" heeft, angezien. Mechelen is komen te "cesseren" en de Hooge Raad van Holland in Zeeland niet bekend is, de processen niet af kunnen loopen. Er wordt niets besloten. Tegen de vergadering van 1 December 1585 staat 't punt weer op de agenda. Den 5en Februari 1586 besluiten de Staten van Zeeland, behalve de stad Middelburg, zich onder 't ressort van den Boogen Raad van Holland te stellen en daarover te onderhandelen. In de Staten van Holland wordt bu (9/19 April 1586) een commissie benoemd, waarin 0. a. OLDENbarneVEIT zitting heeft, om met de Zeeuwen hierover te onderhandelen. In de vergadering van $22 \mathrm{Juli} / 9$ Aug. worden voorloopig vastgesteld de voorwaarden van toetreding; 26 Nov./9 Dec. worden de onderhandelingen met Middelburg over toetreding als door Middelburg gestankt beschouwd, looh den 29 en October 1586 deelt men mede, dat Middelburg ze wilde hervatten, en wordt dit goedgevonden. Bij deze gelegenheid legden echter de afgevaardigden van Dordrecht de verklaring af, dat huns inziens na den dood van den Prins de Hooge Raad geen reden van bestaan meer had, ja zelfs verklaarden zij, dat Dordrecht de kosten er van niet mee wilde oragen en zich niet beschouwde als nog aan de 
Ten slotte wensch ik de resultaten van het onderzoek in een paar woorden samen te vatten.

In 1572 heeft de Prins bij de oprichting van het nieuwe Hof in het midden gelaten of hij het oude hof reconstrueerde dan. wel een nieuw creëerde. Niettemin was het $m$. i. zijn bedoeling het toen gansch niet meer nieuwe denkbeeld te verwezenlijken, om zaken van justitie aan andere handen toe te vertrouwen dan die der politie, een splitsing, die, gelijk ik zeide, in gewest, stad en dorp sinds lang, zij het nooit in streng doorgevoerde consequenties, werd toegepast. Op één dag bij twee besluiten richtte de Prins dus op: een college ran politie en een ander van justitie. Doch met de oprichting van dit laatste college, dat in elk geval ten aanzien der justitie de voortzetting was van het oude regeeringslichaam, wiens naam het overnam, moest voorzichtigheid worden betracht. Niet gemakkelijk ontneemt men historisch geworden rechten, en dit te minder in een zoo hachelijk tijdsgewricht, als 1572 was, wanneer het er op aankomt alles te vermijden wat bij de eigen vrienden vijandschap, althans verkoeling te weeg kan brengen. Ofschoon als college van justitie bedoeld, werd het nieuwe Hof aangesteld op de instructie van het oude, dat regeeringsraad, college van justitie en politie, was. Dit kon te gemakkelijker, omdat die instructie bijna uitsluitend orer zaken van justitie sprak. Een verbod aan de twee in 1572 opgerichte colleges, aan het één om zich met de politie, aan het ander om zich met de justitie te bemoeien, bleef achterwege. En als dan ook het Hof in 1573 aanspraak maakt op het recht van attache, geeft de Prins onmiddellijk toe. De Staten van Holland stonden ten opzichte van de splitsing van justitie en politie op 't standpunt van den Prins; zeer begrijpelijk, elke aanmatiging van gezag op 't gebied der politie, die 't Hof zich veroorloofde, was een ondermijning van het souverein gezag der Staten, die op dit punt zeer gevoelig

rechtspraak van "den Hoogen Raad onderworpen. Ook voor de onderhandelingen met Middelburg wordt een commissie ingesteld, met Octenganevect er in. Zie verder de res. op 6 Nov. 1586; 12 Juni, 15 Juli en 13 Aug. 1587. (Den 4en Juni heeft Alkmaar ter vergadering van de Staten van Holland te kennen gegeven, dat zij den H. R. in Alkmaar gevestigd wilde zięn; die van den Boogen Raad zelf zouden den wensch daartoe to kennen gegeven hebben. Wel zonderling!) 
waren. Op een ander punt: de vestiging van een Raad van Appèl in de plaats van den Grooten Rand te Mechelen, was het ongetwijfeld 's Prinsen wensch zulk een centraal college voor al de gewesten, die zich daaronder mochten scharen, te vestigen.

Dat de Staten van Holland sinds 1579 zich bij dit streven van den Prins hebben aangesloten, toen zij aanstuurden op de vestiging van een vast college van hooger beroep boven het Hof wan Folland, waaronder zich, naar de Staten uitdrukkelijk verklaren, op den duur andere gewesten, konden aansluiten, zal mede hierin verklaring vinden, dat de Staten, gekant tegen de gexagsaanmatigingen van het Hof, en zijn bemoeiingen met zaken van politie, het uit politiek oogpunt nuttig vond dit het Hof in te scherpen door een hooger college in te stellen. De gansche republiek door zou er wrijving zijn tusschen den Hoogen Raad en het Hof ; het Hof, waarin de tradities van den ouden Regeeringsraad voortleefden, en dat enkele rechten en voorrechtjes er van had overgehouden, kon geen hooger college boven zich verdragen; de Hooge Raad voelde zich hooger, maar kon die oude historische regeeringsrechten en voorrechtjes van 't Hof niot goed velen. Vandaar soms de meest kinderachtige resoluties dezer hooge Staatslichamen.

Maar al bevorderde de instelling van een Hoogen Raad de wenschen van de Staten van Holland, om het Hof niet als concurreerend overheidsorgaan naast zich te zien, dit was niet de eenige, $m$. i. ook niet de hoofdreden, waarom de Staten een Raad van Appèl boven het Hof hebben gewild. Een hoogere instantie dan het Hof schijnen zij, om welke reden dan ook, gewenscht te hebben. Dit toont $m$. i. de gang van zaken, eerst met de Commissarissen van Revisie en daarna met de voorbereiding van den Hoogen Raad, onomstootelijk aan. Men kan niet aannemen dat op dit punt de Staten eenvoudig dansten naar de pijpen van den Prins. Dat men zich niet opnieuw onder Mechelen stelde, ofschoon dit na 1580 gemakkelijker kon en men ook wel maatregelen had kunnen treffen, om aan elk gewest zijn invloed op de samenstelling van den Grooten Raud in Mechelen te geven, vindt zijn verklaring hierin, dat Holland, zich eigen kracht langzamerhand bewust geworden, beter vond binnen eigen grenzen dit college te zien opgericht. Zij wilden ran den Centralen Raad van Justitie nevens Anjou niets weten, maar al waren zij dus 
tegen een zich scharen onder een te ver verwijderd Hof gekant, allerminst zou ik willen concludeeren, dat het hun bedoeling was enkel Zeeland onder den Hoogen Raad op te nemen. De bewoordingen van de resolutie van November 1579 zeggen ondubbelzinnig, dat men ' $t$ college zoo deugdelijk moet samenstellen, dat b.v. Friesland en Utrecht ook wenschen zich er onder te begeven. Er is geen reden denkbaar, waarom zij dit in een resolutie zouden zeggen, als zij 't tegenovergestelde meenden. Kortom het besluit van Holland tot oprichting ran den Hoogen Raad was, hoe vreemd het moge schijnen, geheel in de richting van den Prins, om een grondslag te leggen roor een centraal college ran rechtspraak roor de gansche republiek. Is het wel zoo vreemd? Centralisatie op 't gebied van rechtspraak behoefde niet te leiden tot centralisatie op 't gebied der souvereiniteit; elke provincie, die zich onder den Hoogen Raad sehaarde, bleef naar eigen wetten geregeerd en berecht, daarvoor konden en zouden de Souvereino provinciën. Holland in de allereerste plaats, zorgen! Hoe het mogelijk was, dat men rooveel instanties kon wenschen, terwijl men toch het Hof met de bekwaamste juristen kon voorzien?

Niet ten onrechte wordt in de Staatsinstellingen van FrumColenzrander, , bl. 352, de Hooge Rand genoemd het vijfde wiel aan den wagen. In dien geest liet ook het Hof van Holland en Zeeland zich uit in 1663. Men weet dat men in die dagen pogingen heeft aangewend de twee colleges (Hof en Hoogen Raad) samen te smelten, en dat daarover de adviezen van beide zijn ingewonnen. Men vindt deze afgedrukt in de resolutiën der Staten van Holland van 21 Maart 1663. In bet Advies van 't Hof komen eenige merkwaardige beschouwingen voor, welker juistheid - behoudens op één enkel punt - m.i. wordt aangetoond door de feiten, waarvan ik in de voorafgaande bladzijden mededeeling deed. Het Hof zegt, dat de Hooge Raad is gekomen ter vervanging van den Grooten Raad van Mechelen, en dat de oprichting van dit laatste college zeer zeker niet als een privilege door de ingezetenen van Holland is beschouwd; integendeel, tegen hun zin heeft "Hartogh $\mathrm{C}_{A R E L}$ vaN BocRgoIGNe, ghesproten uyt den huyze van Vranckrijck", den Grooten Raad in 't afgelegen Mechelen opgericht, om de Vereenigde Nederlanden door neen opperste ressort van justitie (waer 't mogelijek) te redigeren tot 
een Souverainiteyt." De Staten dezer landen consulteerde hij er niet over; de ingezetenen hebben later onder Vrouw Maria weten te bewerken, dat deze Raad werd te niet gedaan; ja, de leden vau den Raad van Mechelen hebben ter nauwernood door de vlucht er 't leven kunnen afbrengen. Vorder zegt 't Hof, dat "de oorzaecke van erectie van den Hoogen Raedt in Hollandt, in plaatse van de voorschreven Grooten Raede tot Mechelen" niet was geweest on de justitie te dienen, "maer voornamentlijck het ooghmerck, dat men hadde, omme d'andere Geunieerde Provinciën oock onder denselven Hoogen Raede te brenghen in 't stuck van justitie, ghelijck bleeck uyt de resolutie van Haer Edele Groot Moge, in date den 21 November 1579 , ten eynde deselve soude mogen strecken tot een band van de Unie, omme wech te nemen ende te decideren" de geschillen tussehen kwartieren en steden. Hiervan - zoo gaat het Hof voort - kwam niets, want andere provineiën, behalve Zeeland, stelden zich niet onder den Hoogen Raad en in het tractaat van 13 Angustus 1587 met Zeeland staat juist dat de Hooge Raad van dergelijke geschillen geen kennis zou nemen, terwijl bij de Instructie van den Hove en bij art. 1 van het Provisioneel Accoord van 7 Maart 1607 deze quaesties zijn gelaten bij 't Hof' en hiermee juist de oorzaak van de oprichting van den Hoogen Raad ophield, zoodat de samensmelting van Hoogen Raad en Hof tot een college anbeveling verdient ${ }^{1}$ ).

Met hetgeen 'Tonckens schreef, op bl. 66/67 van zijn hierboven vermeld opstel in de Bijdragen voor Vaderl. Gesch, en Oudh.k., over de oprichting van den Hoogen Raad, vereenig ik mij ten volle: "Van dezen maatregel kan niet gezegd worden, dat hij gelukkig is geweest; dit niet in de geschiedenis wortelende, kunstmatige en overbodige rechtscollege heeft wel gedurende ruim twee eeuwem cen aanzienlijke plants in Holland ingenomen, maar is in 1795 verdwenen als een vallende ster, zonder gemist te worden en zonder eenig spoor achter te laten dan een deel van zijn naam, later (in 1838) gegeven aan het toen opgerichte

1) In deze beschouwing van 't Hof komt m.i. een onjuistheid voor. Gelijk ik reeds zeidc: om welke reden dan ook, men heeft, nadat Mechelen had „gecesseerd". niet alleen voor quaesties tussehen kwartieren en steden onderling, maar ook voor processen tusschen particulieren een derde instantie gewild. 
Nederlandsche Hof van Cassatie, den Hoogen Raad der Nederlanden, dat echter niets nitstaande heeft met de schepping $\operatorname{van} 1582^{\prime \prime}$.

Nog één mededeeling tot besluit. Ik heb reeds gezegd, dat de door den Prins in 't oog gevatte splitsing ran justitie en politie ten. opzichte van de werkzaamheden van 't Hof geheel in den geest was van de Staten van Holland, die ook in den vervolge ijverig er voor waakten, dat Hooge Raad en Hof zich niet gezag aanmatigden op het gebied der politie, en dat zij niet alleen het politiek geza.g der Staten, maar ook, en veel meer nog, dat der Steden eorbiedigden. Bij de z.g. scherpe resolutie der Staten van Holland van 4 Augustus 1617 1) wordt allen colleges van justitie verboden kennis te nemon van klachten over maatregelen, door de burgemeesteren en regeerders genomen in zake de religie-questies. In de resolutie derzelfde Staten van 12 Juli 1674 (G.P., III, bl. 495) wordt overwogen, dat het Hof van Holland vóór de „erectie van de Republiek" eenigszins was gemoeid in zake van politie; dat echter van die "erectie der Republiek" af de kennisneming van zaken van politie aan de Hoven was onthouden en dat ook voortaan de Hover (dat zijn dus Hooge Raad en Hof beide) zich hebben te onthouden van zaken, die politiek zijn, en zich enlkel hebben te bemoeien met de administratie der justitie.

De drukproef van het voorafgaande stelde ik an Mr. Tonckens ter hand, die naar aanleiding daarvan nog de volgende opmerkingen maakte.

Het merkwaardige van de ordonnantie van 12 December 1577 (bl. 438 e.v.), zie ik vooral hierin, dat de Prins daarin ,hoog noodig" noemt "voor de justitie" een hooger beroep van alle sententiën van het Hof, waarvan, naar mijn overtuiging, niemand beter begreep dan hij, dat dit beroep totaal overbodig was en in gezonden zin irrationeel ook. Bovendien werd het door niemand gewenscht, hoewel in het schrijven van de Staten van 15 November 1577, aan het Hof gericht, dat natuurlijk dnor den Prins was in de pen gegeven, het wordt voorgesteld, alsof daar-

1) Zie DE Bi.Écovat en JAsikse, Klein Plakikatboelh, bl. 240/242. 
over bitter was geklaagd, wat stellig fantasie was, als men nagaat hoe weinig gebruik is gemaakt van de gelegenheid tot hoogere roorziening, toen deze bestond bij den Grooten Raad van Mechelen en later bij de commissarissen tot revisie ${ }^{1}$ ).

De Prins begon reeds dadelijk toen hij het Hof instelde, bij de resolutie van 3 November 1572, en toen hij bepaalde, dat het voorloopig recht zou doen zonder hooger beroep, zoodanig beroep als nuttig en noodig voor te stellen, en daarvan zeer handig gebruik te maken voor zijn toekomstplannen. Dat hij niet zijjn eigenlijk motief vermeldde, kan men hem niet envel duiden. Handig opereeren was zijn specialiteit.

Aardig is ook dat de Staten met den Prins meewerkten, om den Hoogen Raad in 't levon te roepen, hoewel zij zeer waarsohijnlijk het doel van den Prins, dat m. i. zonder eenigen twijfel was eene eenheid van Noord Nederland voor te bereiden, niet hebben gekend. Hun motief, waarom ze gaarne een college hadden boven het Hof, is vermoedelijk geweest dat zij de machtsconcurrentie van het $H$ of voor zich minder vreesden, naarmate het Hof minder macht had, wat misschien niet vẹrkeerd was gezien. Strijd tusschen administratie en justitie makkt de karak-

1) Deze opmerkingen van TunckENs ondersehrijf ik niet. Ik zal niet herhalen wat gezegd is op bl. 458 e. v. M. i. ziet Tonckens te veel de hand van den Prins in alles. Uit het beloop der zaak blijkt naar mijn meening, dat de Staten een hoogere instantie wenschten; 't is nu maar de vraag of dit enkel was, om 't Hof er onder te krijgen, dan of het ook om 't appèl zelf te doen was. Het eerste is mogelijk, want dat de Staten in de zeventiger jaren herhaaldelijk het Hof duidelijk hebben gemaalst, door tal van resolnties, dat ze zich van de kennisneming ran deze of gene zaak, als zijnde politiek, verder hadden te onthouden, kan men in de Resolutiën der Staten van Holland lezen. (Vgl. de klacht der Zeeuwen, op bl. 450 ter sprake gebracht.) Over "weinig" of "veel" valt soms moeilijk te twisten; er is een lijst van de Hollandsche zaken, in Mechelen behandeld, ten Algemeen Rijksarchieve door Tonckess geraadpleegd. Wat het antal zaken betreft, later, nadat Mechelen niet meer openstond, in revisie behandeld, men kan uit noot 1 op bl. 436 zien, dat in éen jaar de Staten van Holland zeven keer reviseurs hebben benoemd; dit is m. i. niet weinig. Hoeveel revisies vau de vaste commissie van reviseurs zijn behandeld in de periode $1577 / 1582$ is niet na te gaan, omdat de archivalia dezer commissie, die ter griffic van den H. R. moeten zijn gedeponecrd, niet meer in liet archief van den H. R. zijn te vinden. (Vgl, bl. 447,448, in verband met bl. 440/442.) 
ters „klein". De geschiedenis van Nederland levert daarvan, naar

$\rightarrow$ ik meen, in de $19 \mathrm{e}$ eeuw voorbeelden. Leerzaam is te dezerr opzichte het gelukkin nu niet meer actueele geschrift van DE: Jonge, Administratie en Justitie. En ik heb buiten Nederland. er nog voorbeelden van bijgewoond.

Het Hof van Holland heeft te Utrecht in of na 1572 nog: sententiën gewezen; dit blijkt uit een decisie van 25 Februarii 1585 van het Hof, luidende: „Is bij den Hove verstaan ende geresolveert, dat alle de sententiën, geweezen door den voorsz. raedt, sullen gehouden werden voor nul ende van geender waarde", boven welke resolutie staat: "Uytgeweken raedt tot Utrecht". (Decisiën en Res. v. d. Hove v. Holl., n. 350. De samensteller, Anthony DuYck ${ }^{1}$ ), veronderstelt, dat iemand, die zulk eene sententie verkregen had in 1585 , eene poging gedaan zal hebben die te executeeren en dat die omstandigheid aanleiding zal hebben gegeven tot deze decisie).

Een enkel woord nog over de "attache". Het Hof deed alsof dit een recht was, dat heel wat beteekende. (Vgl. bl. 433/434.) Het was integendeel een plicht, dien het had te verrichten in dienst van het uitvoerend gezag ${ }^{2}$ ).

Toen de H. R. van Holland en Zeeland in 1795 is ngemortificeerd", is er weer (als in 1575) gelegenheid gegeven tot hoogere

1) Zie over deze Dec, en Res. en Divcs's auteurschap Mrrars' opstel: Uitgegecen en onailgegeven rechtspraak oan ten $H . R .$, in dit Tigdsehrif, $\mathrm{I}$, bl. $404 / 405$.

2) Ik ben of' dit punt niet geheel van 't gevoelen van Mr. T. Er zou over "plicht" of "recht", ook en vooral ton opzichte van 't Hof van Holland vódr de herstelling van 1572, nog weì een en ander te zeggen zijn, als men denkt aan de Fransche parlementeut en hun droit d'enregistrement, doch, angenomen dat het cen plicht was, van het nienwe Hof stond m.i. na 1572 niet zoo onomstootelijk vast, dat het zich enkel mot justitie had te bemoeien (vgl. bl. 431., noot 1 . en 2 , en bl. 452); op do noodzakelijkheid van attache wees het Hof, om deze als zijn plicht, en daardoor tevens een kentceken van 't behoud van zijn politicke tauk te zien erkend. Voor dit op gezag tak zijnd college: was plicht, mits er geen ondergesehiktheid uit voortvloeide, reht. Mr. T. gaat met mijn heschon wingen van bl. 452 en var bl. 431 , noot 1 en 2 , niet geheel accoord. Z. i. is er wel een seherpe scheiding gemaakt in 1572 en past de attache van 't Hof niet in 't tocn geschapen systeem. 
voorziening van sententiën van het Hof; de „commissarissen ter revisie" herleefden ${ }^{1}$ ).

1) Onder de anteekeningen, die ik Prof. oE Bctcourt ter hand stelde, was een aantal betreffende de processen, in zulke revisiezaken gevoerd, welke processen geen juridieke beteekenis hobben, maar wel curiosa zijz, waarvan ik hoop dat Mr. DF B. nog eens tijd en lust zal hebben iets mee te deelen. 